\title{
An Analytical Study of Translation of Stream of Consciousness in the Novel The Sound and the Fury and Its Two Persian Translations by Sholevar and Hosseini: A Hallidayan Perspective
}

\author{
Mohammad Reza Talebinezhad \\ Islamic Azad University, Shahreza Branch, Iran \\ Email: talebinejad@iaush.ac.ir \\ Pooria Alirezazadeh \\ Islamic Azad University, Shahreza Branch, Iran \\ Email: palirezazadeh@yahoo.com
}

\begin{abstract}
This study is a step towards translation of stream of consciousness within the framework of Halliday's model of language and discourse (1994). The key problem with translation of literary works written in the field of stream of consciousness is that the complex structure of original work can be questionable for translators to convey the specific textual features of the original text. Most of the studies reviewed so far, however, suffer from the fact that they have paid little attention to the grammatical structure and textual features of stream of consciousness as writing style. To this end, the present study employed a descriptive method to compare and analyze metafunctions and lexicogrammatical patterns of the original work along with its two Persian translations to seek matches/mismatches occurring in translation process by taking into consideration of the specific structure of the original work employed by the author, and application of Halliday's model (1994) in translation from English into Persian.
\end{abstract}

Index Terms — stream of consciousness, Halliday's model, translation

\section{INTRODUCTION}

By definition, stream of consciousness is a name for introducing the specific method of narration "that undertakes to reproduce, without a narrator's intervention, the full spectrum and continuous flow of a character's mental process, in which sense perceptions mingle with conscious and half-conscious thoughts, memories, expectations, feelings, and random associations" (Abrams, 1999, p. 299). Applying stream of consciousness as a certain technique to narrate the character's mental world seems to be problematic for writers who tend to approach their characters' subjective world, According to Steinberg (as cited in Chang, 1993), some linguistic features such as lack of appropriate punctuation, applying ungrammatical structures, incoherent and overlapping sentential forms and abrupt shift from one stream of thoughts into another are needed to depict the essence of stream of consciousness writing style. Taken together, the complex form of this writing style could be problematic for the source language reader to follow main stream of the story and chain of events, accordingly, the same situation may occur for the target language reader. Meanwhile, it is becoming increasingly difficult to ignore the pivotal roles of both translation and translator as the mediators between source language and target language. As Nord (2005) pointed out, the difficulty of source text in the phase of source text analysis can be considered as one of the most serious obstacles during translation process. Despite the importance of the problem in the field of translation studies, so far, however, there has been little discussion about Persian translation of literary works written in the field of stream of consciousness. The researchers to date have tended to focus on other aspects of stream of consciousness, and far too little attention has been paid to the textual and linguistic features of stream of consciousness. Therefore, the present study was designed to seek the analysis of textual characteristics of stream of consciousness in the source text, and reproduction of the given style in the target text in the light of Halliday's model of language and discourse (1994).

Horri (2009) investigated the translator's style in translation of narrative texts, and examined Persian's translation of Woolf's To the Lighthouse in the light of Baker's universals of translation. He put the focus of his study on the importance of the writer's style along with the translator's style considering stylistics of the translator suggested by Baker, and concluded that normalization is the most frequent universal in Hosseini's translation of To the Lighthouse. Wang (2011) conducted a corpus-based study on Chinese translation of Ulysses, and investigated the translator's fingerprint as manifested in his/her style in translation. Wang (2011) came to this conclusion that the fingerprints of the translator are left on the translated text both as a result of his/her linguistic idiosyncrasy and of the interference and 
constraints of the languages s/he is dealing with in translation. In 2011, Kao and Wu published a paper entitled as "Translating Stream of Consciousness in the Light of Adaptation: The Case Study of Faulkner's Quentin Compson in The Sound and the Fury". They draw our attention to the structure of stream of consciousness style employed by Faulkner to show Quentin's puzzlement and astonishment, and claimed that translation without annotation may lead to textual inaccessibility for the target reader. To improve textual accessibility, they proposed adaptation to reconstruct stream of consciousness through the use of explicitation and expansion. Obviously, there are similarities between the natures of previous studies and what the present study aims at, such as focus on Faulkner's style to represent stream of consciousness and proposing translation strategies to handle problematic translation of The Sound and the Fury (1995). The issue of stream of consciousness has been a controversial and much disputed subject within the field of translation, undoubtedly, this problem refers to textual features of this style which have became a central issue for reading literary works written in this field, owning to this fact, translation and getting the exact meaning of author and conveying the intended meaning are the major issues in the field of translation studies. With regard to these problems, the present study seeks to address translation of stream of consciousness and application of Halliday's model (1994) in practical aspect of translation from English into Persian simultaneously. As Bosseaux (2007) acknowledged.

Halliday's model (1971, 1976 and 1985/1994) is based on systemic functional grammar (SFG). A functional grammar considers that language performs a number of different functions and that any piece of language is likely to be result of choices made on different functional levels. It is designed to account for how language is used and claims that everything can be explained, ultimately, by reference to this. The theory behind Halliday's account is also known as systemic since it is a theory of meaning as choice, by which a language is interpreted as a network of interlocking options. Halliday's model is designed for the study of language as communication; meaning is attributed to the writer's speaker's motivated linguistic choices, which systemically relate to a wider sociocultural framework. Halliday's model provides a detailed analysis of three interconnected elements of meaning or metafunctions in a text. These metafunctions are the metafunctions in the linguistic system of three general purposes, which underlie all uses of language and are the functions. They are namely the ideational, interpersonal and textual metafunctions. (pp. 24-25)

Eggins (1994, as cited in Munday, 2001) acknowledged that analysis of metafunctions is the heart of the Halliday's model, and the close relationship between lexicogrammatical patterns and metafunctions help us to understand a text.

\section{METHODOLOGY}

\section{A. Materials}

In order to seek the matter in question, three chapters of William Faulkner's novel The Sound and the Fury (1995) known as one of the notable fictional works in the realm of stream of consciousness along with its two Persian translations by Sholevar (2004) and Hosseini (2009) have been selected. In order to understand the plot of the story, and to avoid deviations and misunderstandings occurring during the analysis of the original text, Critical Companion to William Faulkner: A literary Reference to His Life and Work (2008) by Fargnoli, Golay, and Hamblin has been chosen. Some required definitions and functions of words in the original text have been checked by Longman Dictionary of Contemporary English CD-ROM (2005). In order to obtain the frequency and percentage of data, Microsoft Office Excel (2007) has been employed.

\section{B. Text Selection}

As confirmed by Volpe (2003), the original text is narrated through three characters' minds with three different viewpoints. Owning to this, samples of stream of consciousness writing style have been selected on the basis of the narrator's different viewpoints, and analyzed separately.

\section{Procedure}

In order to acquire data and deduce conclusions, $30 \%$ of the best samples of stream of consciousness were extracted from each chapter of the original work, to compare the original work and translations, after the original text analysis, translations of the samples extracted from two Persian translations of the novel were analyzed clause by clause on the basis of Halliday's model of language and discourse (1994) to obtain constituents of required grammar for each type of meanings. For each case of three types of meaning in the original work, two Persian translations were checked to see whether Persian translations would match the required grammar of each type of meanings. Findings obtained from this comparison were analyzed in terms of differences and changes made by translators, to see whether they would change the meaning. If changes affected the meaning, analysis would seek to address in what sense and how did changes affect the meaning.

\section{RESUlts AND DATA ANALYSIS}

This section includes all statistical information including frequency and percentage of the grammatical constituents of each type of meanings obtained from comparison between the original text and its two Persian translations.

The table below illustrates the frequency and percentage of the grammatical constituents of experiential meaning obtained from the first chapter of the original text and its two Persian translations. 
TABLE 1

FREQUENCY AND PERCENTAGE OF GRAMMATICAL CONSTITUENTS OF EXPERIENTIAL MEANING IN CHAPTER ONE

\begin{tabular}{|l|l|l|l|}
\hline & Original Text & $\begin{array}{l}\text { Sholevar's Translation } \\
\text { F. (\%) }\end{array}$ & $\begin{array}{l}\text { Hosseini's Translation } \\
\text { F. (\%) }\end{array}$ \\
\hline Actor & 62 & $40.64 .5 \%$ & $37.60 \%$ \\
\hline Senser & 13 & $9.69 .2 \%$ & $3.23 \%$ \\
\hline Sayer & 4 & $2.50 \%$ & $2.50 \%$ \\
\hline Carrier & 10 & $7.70 \%$ & $6.60 \%$ \\
\hline Behaver & 4 & $1.25 \%$ & 0 \\
\hline Goal & 19 & $19.100 \%$ & $19.100 \%$ \\
\hline Circumstance & 58 & $57.98 .2 \%$ & $58.100 \%$ \\
\hline Beneficiary & 4 & $4.100 \%$ & $4.100 \%$ \\
\hline Receiver & 1 & $1.100 \%$ & $1.100 \%$ \\
\hline Verbiage & 0 & 0 & 0 \\
\hline Attribute & 9 & $8.89 \%$ & $8.89 \%$ \\
\hline Phenomenon & 12 & $12.100 \%$ & $12.100 \%$ \\
\hline Range & 2 & $2.100 \%$ & $2.100 \%$ \\
\hline Existent & 0 & 0 & 0 \\
\hline Process: material & 02 & $76.97 \%$ & $79.96 \%$ \\
\hline Process: mental & 13 & $13.100 \%$ & $13.100 \%$ \\
\hline Process: verbal & $4.100 \%$ & $4.100 \%$ \\
\hline Process: behavioural & 5 & $4.80 \%$ & $4.80 \%$ \\
\hline Process: existential & 0 & 0 & 0 \\
\hline Process: intensive & 10 & $9.90 \%$ & $9.90 \%$ \\
\hline
\end{tabular}

The table below illustrates the frequency and percentage of the grammatical constituents of interpersonal meaning obtained from the first chapter of the original text and its two Persian translations.

TABLE 2

FREQUENCY AND PERCENTAGE OF GRAMMATICAL CONSTITUENTS OF INTERPERSONAL MEANING IN CHAPTER ONE

\begin{tabular}{|l|l|l|l|}
\hline \multicolumn{2}{l}{ FREQUENCY AND PERCENTAGE OF GRAMMATICAL CONSTITUENTS OF INTERPERSONAL MEANING IN CHAPTER ONE } \\
\hline & Original Text & $\begin{array}{l}\text { Sholevar's Translation } \\
\text { F. (\%) }\end{array}$ & $\begin{array}{l}\text { Hosseini's Translation } \\
\text { F. (\%) }\end{array}$ \\
\hline Subject & 94 & $59.63 \%$ & $50.53 \%$ \\
\hline Finite & 84 & $84.100 \%$ & $84.100 \%$ \\
\hline Finite: modal & 12 & $5.42 \%$ & $3.25 \%$ \\
\hline Adjunct: circumstantial & 63 & $55.87 \%$ & $62.98 \%$ \\
\hline Adjunct: conjunctive & 41 & $41.100 \%$ & $41.100 \%$ \\
\hline Adjunct: continuity & 0 & 0 & 0 \\
\hline Adjunct: mood & 2 & $2.100 \%$ & $2.100 \%$ \\
\hline Adjunct: vocative & 1 & $1.100 \%$ & $1.100 \%$ \\
\hline Predicator & 107 & $105.98 \%$ & $102.95 \%$ \\
\hline Complement & 39 & $39.100 \%$ & $39.100 \%$ \\
\hline
\end{tabular}

The table below illustrates the frequency and percentage of Theme types obtained from the first chapter of the original text and its two Persian translations.

TABLE 3

FREQUENCY AND PERCENTAGE OF THEME TYPES IN CHAPTER ONE

\begin{tabular}{|l|l|l|l|}
\hline & Original Text & $\begin{array}{l}\text { Sholevar's Translation } \\
\text { F. }(\%)\end{array}$ & $\begin{array}{l}\text { Hosseini's Translation } \\
\text { F. }(\%)\end{array}$ \\
\hline Topical Theme & 98 & $61.62 \%$ & $50.51 \%$ \\
\hline Textual Theme & 33 & $33.100 \%$ & $33.100 \%$ \\
\hline Interpersonal Theme & 2 & $1.50 \%$ & $1.50 \%$ \\
\hline
\end{tabular}

The table below illustrates the frequency and percentage of the grammatical constituents of experiential meaning obtained from the second chapter of the original work and its two Persian translations. 
TABLE 4

FREQUENCY AND PERCENTAGE OF GRAMMATICAL CONSTITUENTS OF EXPERIENTIAL MEANING IN CHAPTER TwO

\begin{tabular}{|l|l|l|l|}
\multicolumn{2}{l}{ FREQUENCY AND PERCENTAGE OF GRAMMATICAL CONSTITENTS OF EXPERIENTIAL MEANING IN CHAPTER TWO } \\
\hline & Original Text & $\begin{array}{l}\text { Sholevar's Translation } \\
\text { F. }(\%)\end{array}$ & $\begin{array}{l}\text { Hosseini's Translation } \\
\text { F. (\%) }\end{array}$ \\
\hline Actor & 28 & $17.60 \%$ & $18.64 \%$ \\
\hline Senser & 4 & $1.25 \%$ & $1.25 \%$ \\
\hline Sayer & 6 & $5.83 \%$ & $3.50 \%$ \\
\hline Carrier & 19 & $11.58 \%$ & $11.58 \%$ \\
\hline Behaver & 3 & $2.67 \%$ & $3.100 \%$ \\
\hline Goal & 19 & $18.95 \%$ & $18.95 \%$ \\
\hline Circumstance & 53 & $52.98 \%$ & $52.98 \%$ \\
\hline Beneficiary & 2 & $2.100 \%$ & $2.100 \%$ \\
\hline Receiver & 0 & 0 & 0 \\
\hline Verbiage & 1 & $1.100 \%$ & $1.100 \%$ \\
\hline Attribute & 21 & $19.90 \%$ & $21.100 \%$ \\
\hline Phenomenon & 3 & $3.100 \%$ & $3.100 \%$ \\
\hline Range & 1 & 0 & $1.100 \%$ \\
\hline Existent & 5 & $4.80 \%$ & $2.50 \%$ \\
\hline Process: material & 42 & $42.100 \%$ & $42.100 \%$ \\
\hline Process: mental & 7 & $7.100 \%$ & $7.100 \%$ \\
\hline Process: verbal & 6 & $5.83 \%$ & $6.100 \%$ \\
\hline Process: behavioural & 3 & $3.100 \%$ & $3.100 \%$ \\
\hline Process: existential & 2 & $2.100 \%$ & $1.50 \%$ \\
\hline Process: intensive & 15 & $15.100 \%$ & $15.100 \%$ \\
\hline
\end{tabular}

The table below illustrates the frequency and percentage of the grammatical constituents of interpersonal meaning obtained from the second chapter of the original work and its two Persian translations.

TABLE 5

FREQUENCY AND PERCENTAGE OF GRAMMATICAL CONSTITUENTS OF INTERPERSONAL MEANING IN CHAPTER TwO

\begin{tabular}{|l|l|l|l|}
\hline \multicolumn{2}{l}{ FREQUENCY AND PERCENAGG OF GRAMMATICAL CONSTIUENTS OF INTERPERSONAL MEANING IN CHAPTER TWO } \\
\hline & Original Text & $\begin{array}{l}\text { Sholevar's Translation } \\
\text { F. }(\%)\end{array}$ & $\begin{array}{l}\text { Hosseini's Translation } \\
\text { F. }(\%)\end{array}$ \\
\hline Subject & 58 & $31.53 \%$ & $35.60 \%$ \\
\hline Finite & 46 & $46.100 \%$ & $46.100 \%$ \\
\hline Finite: modal & 8 & $7.87 .5 \%$ & $7.87 .5 \%$ \\
\hline Adjunct: circumstantial & 45 & $42.93 \%$ & $45.100 \%$ \\
\hline Adjunct: conjunctive & 20 & $20.100 \%$ & $20.100 \%$ \\
\hline Adjunct: continuity & 0 & 0 & 0 \\
\hline Adjunct: mood & 5 & $4.80 \%$ & $5.100 \%$ \\
\hline Adjunct: vocative & 9 & $8.89 \%$ & $8.89 \%$ \\
\hline Predicator & 63 & $63.100 \%$ & $63.100 \%$ \\
\hline Complement & 48 & $41.85 \%$ & $45.98 \%$ \\
\hline
\end{tabular}

The table below illustrates the frequency and percentage of Theme types obtained from the second chapter of the original text and its two Persian translations.

TABLE 6

FREQUENCY AND PERCENTAGE OF THEME TYPES IN CHAPTER TWO

\begin{tabular}{|l|l|l|l|}
\hline \multicolumn{2}{l}{ FREQUENCY AND PERCNTAGE OF THEME TYPES IN CHAPTER TWO } \\
\hline & Original Text & $\begin{array}{l}\text { Sholevar's translation } \\
\text { F. }(\%)\end{array}$ & $\begin{array}{l}\text { Hosseini's Translation } \\
\text { F. }(\%)\end{array}$ \\
\hline Topical Theme & 69 & $37.57 \%$ & $36.52 \%$ \\
\hline Textual Theme & 16 & $16.100 \%$ & $14.87 .5 \%$ \\
\hline Interpersonal Theme & 17 & $12.70 .5 \%$ & $15.88 \%$ \\
\hline
\end{tabular}

The table below illustrates the frequency and percentage of the grammatical constituents of experiential meaning obtained from the third chapter of the original work and its two Persian translations. 
TABLE 7

FREQUENCY AND PERCENTAGE OF GRAMMATICAL CONSTITUENTS OF EXPERIENTIAL MEANING IN CHAPTER THREE

\begin{tabular}{|l|l|l|l|}
\hline & Original Text & $\begin{array}{l}\text { Sholevar's Translation } \\
\text { F. }(\%)\end{array}$ & $\begin{array}{l}\text { Hosseini's Translation } \\
\text { F. (\%) }\end{array}$ \\
\hline Actor & 17 & $11.65 \%$ & $10.59 \%$ \\
\hline Senser & 8 & $5.62 .5 \%$ & $2.25 \%$ \\
\hline Sayer & 3 & $3.100 \%$ & $2.67 \%$ \\
\hline Carrier & 4 & $2.50 \%$ & $1.25 \%$ \\
\hline Behaver & 1 & $1.100 \%$ & $1.100 \%$ \\
\hline Goal & 12 & $12.100 \%$ & $12.100 \%$ \\
\hline Circumstance & 22 & $22.100 \%$ & $22.100 \%$ \\
\hline Beneficiary & 1 & $1.100 \%$ & 0 \\
\hline Receiver & 0 & 0 & 0 \\
\hline Verbiage & 1 & $1.100 \%$ & $1.100 \%$ \\
\hline Attribute & 3 & $3.100 \%$ & $3.100 \%$ \\
\hline Phenomenon & 8 & $6.75 \%$ & $8.100 \%$ \\
\hline Range & 0 & 0 & 0 \\
\hline Existent & 0 & 0 & 0 \\
\hline Process: material & 31 & $28.90 \%$ & $24.77 \%$ \\
\hline Process: mental & 10 & $9.90 \%$ & $10.100 \%$ \\
\hline Process: verbal & 4 & $4.100 \%$ & $4.100 \%$ \\
\hline Process: behavioural & 1 & $1.100 \%$ & $1.100 \%$ \\
\hline Process: existential & 0 & 0 & 0 \\
\hline Process: intensive & 4 & $4.100 \%$ & $4.100 \%$ \\
\hline
\end{tabular}

The table below illustrates the frequency and percentage of the grammatical constituents of interpersonal meaning obtained from the third chapter of the original work and its two Persian translations.

TABLE 8

FREQUENCY AND PERCENTAGE OF GRAMMATICAL CONSTITUENTS OF INTERPERSONAL MEANING IN CHAPTER THREE

\begin{tabular}{|l|l|l|l|}
\hline & Original Text & Sholevar's Translation & Hosseini's Translation \\
\hline Subject & 32 & $17.53 \%$ & $10.31 \%$ \\
\hline Finite & 32 & $32.100 \%$ & $32.100 \%$ \\
\hline Finite: modal & 5 & $5.100 \%$ & $4.80 \%$ \\
\hline Adjunct: circumstantial & 22 & $22.100 \%$ & $22.100 \%$ \\
\hline Adjunct: conjunctive & 17 & $17.100 \%$ & $17.100 \%$ \\
\hline Adjunct: continuity & 3 & $2.67 \%$ & $3.100 \%$ \\
\hline Adjunct: mood & 3 & $2.67 \%$ & $3.100 \%$ \\
\hline Adjunct: vocative & 1 & $1.100 \%$ & $1.100 \%$ \\
\hline Predicator & 46 & $43.93 \%$ & $45.98 \%$ \\
\hline Complement & 22 & $22.100 \%$ & $22.100 \%$ \\
\hline
\end{tabular}

The table below illustrates the frequency and percentage of Theme types obtained from the third chapter of the original text and its two Persian translations.

TABLE 9

FREQUENCY AND PERCENTAGE OF THEME TYPES IN CHAPTER THREE

\begin{tabular}{|l|l|l|l|}
\hline & Original Text & $\begin{array}{l}\text { Sholevar's Translation } \\
\text { F. (\%) }\end{array}$ & $\begin{array}{l}\text { Hosseini's Translation } \\
\text { F. (\%) }\end{array}$ \\
\hline Topical Theme & 30 & $14.47 \%$ & $13.43 \%$ \\
\hline Textual Theme & 25 & $20.80 \%$ & $22.88 \%$ \\
\hline Interpersonal Theme & 0 & 0 & 0 \\
\hline
\end{tabular}

\section{DISCUSSION AND CONCLUSIONS}

As mentioned earlier, due to the differences between three narrators' viewpoints, and characteristics of stream of consciousness depicted by Faulkner (1995) in the original text, this section has been divided into three parts. Throughout this section Sholevar's translation (2004) and Hosseini's translation (2009) will be marked as T1 and T2 respectively.

\section{A. Samples of Chapter One}

Sample 1:

He put my hands into my pockets. I could hear him rattling in the leaves. I could smell the cold. The gate was cold.

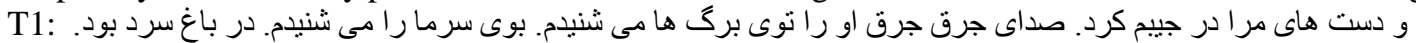

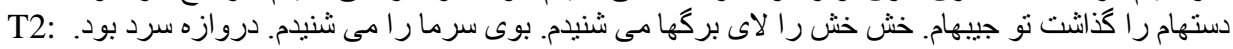

From an experiential meaning viewpoint, it can be seen easily that the constituents "He" and "I" functioning as actor and senser have been omitted in both translations. In the same way, from an interpersonal meaning viewpoint, the aforementioned elements functioning as subject have been omitted in both translations. To certain extent, we can say 
that these omissions did not change the meaning definitely. The supporting evidence behind of this claim is the fact that in both translations the Subject Marker conflated with both process and predicator in experiential and interpersonal meanings confirms the presence of omitted elements.

Consider the highlighted items in the following Persian translations of each clause, the highlighted items indicate the presence of subject in Persian translations.

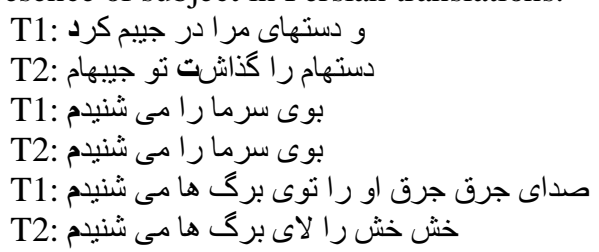

Comparing the original clauses with translations, it can be seen that the constituent "could", what we can label as modal finite in interpersonal meaning, has not been translated by both translators. According to Halliday (1994),

The Finite element, as its name implies, has the function of making the proposition finite. That is to say, it circumscribes it; it begins the proposition down to earth, so it is something that can be argued about. A good way to make something arguable is to give it a point of reference in the here and now; and this is what the Finite does. It relates the proposition to its context in the speech event. This can be done in one of two ways. One is by reference to the time of speaking; the other is by reference to the judgment of the speaker.... In grammatical terms, the first is PRIMARY TENSE, the second is MODALITY. (i) Primary tense means past, present or future at the moment of speaking; it is time relative to 'now'. A proposition may become arguable by having its relevance to the speech event specified in these temporal terms. (ii) Modality means the speaker's judgment of the probabilities, or the obligations, involved in what he is saying. A proposition may become arguable by being presented as likely or unlikely, desirable or undesirable-in other words, its relevance specified in modal terms. (p. 75)

Halliday (1994) divided modality into two subdivisions, Modalization and Modulation. Halliday (as cited in Eggins, 1994) defines modalization as a means to express two kinds of meanings, "1. probability: where the speaker expresses judgments as to the likelihood or probability of something happening or being; and 2. usuality: where the speaker expresses judgments as to the frequency with which something happens or is" (p. 276).

Returning now to the comparison between the original text and two Persian translations in sample 1, it can be seen that both translators have not translated the constituents "could" which can be labeled as Finite Modal Operator. In fact, the narrator's judgment has been overlooked.

Sample 2:

\section{Mrs Patterson came across the garden, running.}

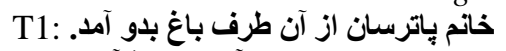

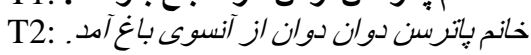

As mentioned earlier, one of the textual features of stream of consciousness is the use of ungrammatical structures. The constituent "running" functions as predicator in the original text, this item has been separated by use of comma without any preceding items.

From a Hallidayian perspective, the above-mentioned clause can be named as elliptical clause. Let us look at what Halliday meant by ellipsis and elliptical clauses. As Halliday and Hassan (1976) pointed out

When we talk of ellipsis, we are not referring to any and every instance in which there is some information that the speaker has to supply from his own evidence. That would apply to practically every sentence that is ever spoken or written, and would be of no help in explaining the nature of a text. We are referring specifically to sentences, clauses, etc where structure is such as to presuppose some preceding item, which then serves as the source of missing information. An elliptical is one which, as it were, leaves specific structural slots to be filled from elsewhere. This is exactly the same as presupposition by substitution, except that in substitution an explicit 'counter' is used... whereas in ellipsis nothing is inserted into the slot.... We can take as a general guide the notion that ellipsis occurs when something that is structurally necessary is left unsaid, there is a sense of incompleteness associated with it. But it is useful to recognize that this is an over-simplification, and that the essential characteristic of ellipsis that something which is present in the selection of underlying ('systemic') options is omitted in the structure-whether or not the resulting structure is in itself ' incomplete'. (pp. 143-144)

Halliday (1994) also added, "in general, every independent clause in English requires a Subject, because without a subject it is impossible to express the mood of the clause, at least in the usual fashion" (p. 93).

It is clear from above that, the predicator "running" was left incomplete, that is to say, mood structure has been omitted, but the function of the given element changed in both $\mathrm{T} 1$ and $\mathrm{T} 2$. It has been translated as circumstantial elements.

\section{Concept of Shift in Translation}

Suggested by Catford (2000, as cited in Munday, 2001), there are two types of shift: shift of level and shift of category. As far as our analysis is concerned, we focus on the second type of shift and its subdivisions from Catford's viewpoint. According to him, shift of category is divided into four subdivisions: Structural shifts which deal with shift in grammatical structures, Class shifts which refer to shift from one part of speech into another, Unit shifts or rank shifts 
take place where equivalents of target language belong to different hierarchical linguistic units, and Intera-system shifts occur when source language and target language have the same corresponding systems approximately, but translation involves non-corresponding terms in the target language system. Consider the following clause extracted from the original text and its two Persian translations:

Then he fell into the flowers, laughing,

T1: بعد همانطور كه مى خنديد توى كل هان

T2: بعد خنده كنان توى كل ها ها

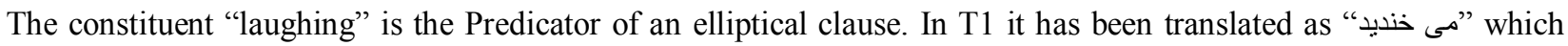
functions as Finite + Predicator. Finite in T1 gives tense to the clause. By contrast, the given elliptical clause in the original text has been translated as a circumstantial element in T2, the participant "خنده كنان" functions as circumstantial adjunct, in other words, here we deal with a class shift.

\section{Theme and Rheme}

As Eggins (1994) pointed out, the point of departure in each clause can be labeled as Theme, and Rheme is served to develop Theme, determining Theme and Rheme boundaries and identification of each item are based on the simple criteria, that is to say, each element that is not theme is Rheme. She acknowledged that "the identification criteria are only true for English, where word order plays a very significant role in the grammar [italic added]" (p. 275). Halliday (1994) identifies three main types of Theme including topical, interpersonal and textual. Eggins (1994) continues that when the first constituent of each clause has Transitivity function, it can be described as topical Theme, if the first constituent has a Mood label, we can call it interpersonal Theme, and those elements which function as cohesive devices served for relating the clause to its context can be described as textual Theme. Pakravan (2002) draws our attention to the fact that "free words order and omission of subject lead to change Theme-Rheme structure in Persian grammar [translation is mine]" (p. 47). To put it another way, due to these features of Persian grammar the point of departure is alterable and does not follow the constant patterns of English Theme-Rheme structure.

Consider the following clause and its two Persian translations:

We went to the library.

T1: بنتيم به كتابخانه.

T2: به كتابخانه ركنية

By definition, the point of departure in the original clause "we" is topical Theme, while T1 begins by " "رفتيم" that functions as material process, due to Persian grammar free words order and definition of the topical Theme in Halliday's model (1994), we can label this item as a topical Theme in T1, by contrast, T2 begins by “بانه كتابخانه" that functions as a circumstantial element, and we can label it as topical Theme in T2.

\section{B. Samples of Chapter Two}

Sample 1:

Thinking what he said about idle habits. Thinking it would be nice for them down at New London if the weather held up like this.

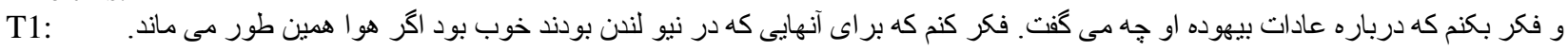

T2: و درباره آنهه از عادهاى بيهوده مى گفت فكر كنم. و فكر كنم كه اكر هوا بر همين منوال مى ماند، براى آنها كه در نيو لندن بودند خوب مى ، شد.

The mood structure of the constituent "thinking" that functions as predicator has been removed in the original text, but it can be identified by referring to the preceding clauses. However, duo to the omission of subjects in T1 and T2, they cannot be treated as elliptical clauses, and presence of subjects can be identified through subject markers conflated with predicators in both translations. The constituent "would" in the original text functions as Temporal Finite Verbal Operator and refers to the time, and gives tense to the clause. Its following element "be" functions as predicator. A closer look shows that "would" is a separate element in the original clause, but it has been conflated with predicator in both $\mathrm{T} 1$ and T2, and it does not exist as a separate element.

Sample 2:

Until on the Day when He says Rise only the flat-iron would come floating up. It's not when you realise that nothing can help you--religion, pride, anything--it's when you realise that you dont need any aid. Dalton Ames. Dalton Ames. Dalton Ames. If I could have been his mother lying with open body lifted laughing, holding his father with my hand refraining, seeing, watching him die before he lived. One minute she was standing in the door

A closer look at the above-mentioned paragraph shows that there are no logical and meaningful relations between clauses, and this is what we know as one of the most important aspect of stream of consciousness writing style manifested in Faulkner's style to create such a complex and puzzling environment through the course of narrating the story which makes the story difficult to follow. Halliday and Hassan (1976) acknowledged that

A text is best regarded as a SEMANTIC unit: a unit not of form but of meaning. Thus it is related to a clause or sentence not by size but by REALIZATION, the coding of one symbolic system in another. A text does not CONSIST OF sentences; it is REALIZED BY, or encoded in, sentences. If we understand it in this way, we shall not expect to find the same kind of STRUCTURAL integration among the parts of a text as we find among the parts of a sentence or clause. The unity of a text is a unity of a different kind. The concept of TEXTURE is entirely appropriate to express the 
property of 'being a text'. A text has texture, and this is what distinguishes it from something that is not a text [italic added]. It derives this texture from the fact that it functions as a unity with respect to its environment. (p. 2)

Eggins (1994) that "when we say the clauses don't hang together, we are reacting to two dimensions of the paragraph: its contextual properties: what we call its coherence; and its internal properties: what we call its cohesion" (p. 87). Text and texture are two terms frequently used in Halliday's approach towards language and linguistics, and this is an important issue in analysis of the second chapter samples. The term text has come to be used to refer to

Any instance of living language that is playing some part in a context of situation, we shall call a text. It may be either spoken or written, or indeed in any other medium of expression that we like to think of. The important thing about the nature of a text is that, although when we write it down it looks as though it is made of words and sentences, it is really made of meanings. Of course, the meanings have to be expressed, or coded, in words and structures, just as these in turn have to be expressed over again-recoded, if you like-in sounds or in written symbols. It has to be coded in something in order to be communicated; but as a thing in itself, a text is essentially a semantic unit. It is not something that can be defined as being just another kind of sentence, only bigger. (Halliday \& Hassan, 1989, p. 10)

Taken together, from Halliday's model viewpoint, identifying a field, tenor and mode for the collection of clauses of sample 2 extracted from chapter two is impossible.

Sample 3:

Father said Uncle Maury was too poor a classicist to risk the blind immortal boy in person he should have chosen Jason because Jason would have made only the same kind of blunder Uncle Maury himself would have made not one to get him a black eye

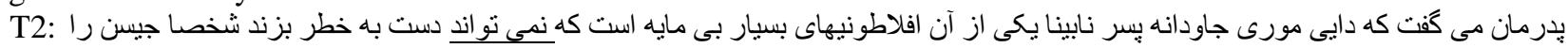

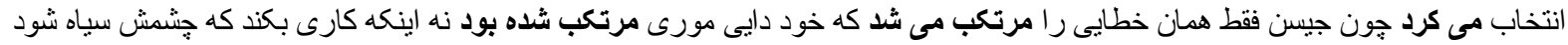

The highlighted elements in the original text function as temporal finite which gives tense to the clauses, a closer look at analysis shows that these items do not exist as a separate element in $\mathrm{T} 2$, and they have been conflated with predicators [highlighted items in T2]. Consider the underlined element in T2 that functions as negative modal finite, indeed translator has conveyed the meaning precisely by adding such an item which does not exist in the original text, in other words, another structural shift occurs again.

\section{Samples of Chapter Three}

Sample 1:

So after a while I heard the band start up, and then they begun to clear out. Headed for the show, every one of them.

Haggling over a twenty cent hame string to save fifteen cents

T1: خلاصده كمى بعد شنيدم كه دسته موزيك شروع كرد و بعد آنها كم كم روانه شدند. بلااستثناء به قصد نمايش راه افتادند سر يك تسمه مال بند

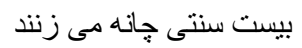

T2: بر اى همين كمى بعد شنيدم كه نوازنده ها شروع كردند، و آن وقت آنها بنا كردند به در رفتن از مغازه. همه يك كله رفتند طرف نمايش. سر يكى

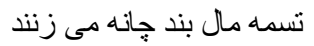

The mood structure of the highlighted items [subject and finite] in the original text has been removed, but the elliptical elements have been conflated with predicator in both translations.

Sample 2:

She had dodged out of sight somewhere. Saw me coming and dodged into another alley, running up and down the alleys with a dam show man in a red tie that everybody would look at and think what kind of a dam man would wear a red tie.

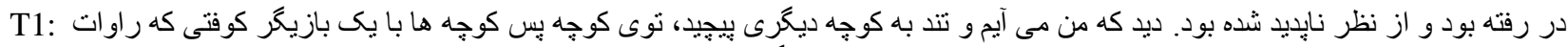

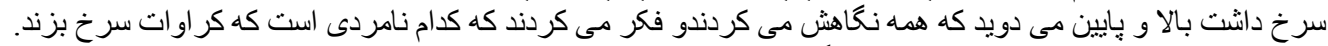

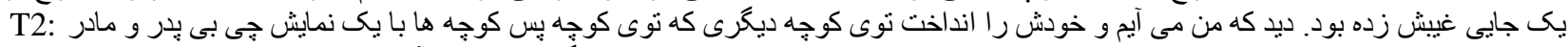

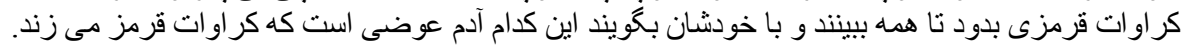

From an interpersonal meaning viewpoint, the constituent "would" that functions as temporal finite does not exist as a separate element in translations, and it has been conflated with predicator, and gives tense to the clause.

\section{Conclusions}

Conclusions derived from the analysis have been divided into two aspects, application of Halliday's model (1994) and translation of stream of consciousness. . From an experiential meaning viewpoint, the participants involved in different process type such as Actor, Sayer, Behaver and Carrier can be omitted in Persian language [active clauses], but this omission does not change the meaning, in the way that the constituent subject marker conflated with the verbal group in Persian grammar can fill this gap and convey the the intended meaning, the only difference existing between Persian and English languages is that the subject marker which plays the role of omitted element cannot be labeled as a separate element in Halliday's model (1994), it only confirms the presence of the omitted constituent. Likewise, from an interpersonal meaning viewpoint, the subject marker attached into the verbal group of a Persian clause confirms the presence of subject, but this marker cannot be labeled as an independent element by itself. The statistical results obtained from data analysis support our findings. The frequencies of participants such as Actor, Sayer, Carrier and Subject in both translations are less than the original text. 
The constituent finite in interpersonal meaning was divided into two main categories, Temporal Finite Verbal Operator and Finite Modal Operator. According to Eggins (1994) the first type is served to give tense to the clause, and the second one is employed to express probability and usuality. The significant conclusions can be drawn from analysis is the fact that although, finite elements have been overlooked by translators over and over again in different parts of the original text, but in general, therefore, it seems that there are no suitable equivalents for each case of finite element in Persian language. To put it another way, according to Halliday (1994), Finite Verbal Operators are divided into different categories to specify the certain degrees and boundaries [Temporal Operators: past, present and future, Modal Operators: low, median and high] existing between these items. Comparing the original text with its two Persian translations reveals us; however, far too little attention has been paid to take account of Persian translation of Finite Verbal Operators. From a Systemic Functional Linguistics viewpoint, the most important limitation in terms of Finite Verbal Operators lies in the fact that unlike English grammar, defining certain boundaries to identify and determine degrees and subdivisions of finite elements in Persian translation is not a simple task, to this end, the findings of this study suggest that in order to convey the exact meaning of finite elements precisely, we need to employ additional items, or apply different types of shift such as class shifts. The reliable evidence to support this claim is the concept of loss and compensation in translation studies. As Bassnet (2005) pointed out

Once the principle is accepted that sameness cannot exist between two languages, it becomes possible to approach the question of loss and gain in the translation process. It is again an indication of the low status of translation that so much time should have been spent on discussing what is lost in the transfer of a text from SL to TL whilst ignoring what can also be gained, for the translator can at times enrich or clarify the SL text as a direct result of the translation process. Moreover, what is often seen as 'lost' from the SL context may be replaced in the TL context. (p. 38)

From a textual meaning viewpoint, identification of Theme-Rheme structure and determination of boundaries to define Theme in Persian clauses can be considered as the most controversial aspect of application of Halliday's model. Halliday (1994) defines Theme in an English clause as a point of departure, as Baker (1992) pointed out

The syntactic structure of a language imposes restrictions on the way message may be organized in that language. The order in which functional elements such as subject, predicator, and object may occur is more fixed in some languages than in others. Languages vary in the context to which they rely on word order to signal the relationship between elements in the clause. (p. 110)

The most convincing and supporting evidence to prove this claim is the constant words order in English clauses versus free words order in Persian clauses. Consequently, the concept of Theme as a point of departure in English language differs from Persian language, the most tangible aspect of this difference manifests in translation of declarative clauses [active and passive].

In the final part of conclusions, we have to focus on the translation of stream of consciousness. To certain extent, both translators have tried to employ explicitation as a certain strategy to present their works. Sholevar (2004) and Hosseini (2009) have made attempts to provide background information about the novel by addressing the author's biography and works, literary criticism of the novel and the characteristics of stream of consciousness as a writing style. To some extent, Sholevar (2004) has succeeded to provide background information about The Sound and the Fury (1995). First of all, he has introduced William Faulkner and his works, then, he has concentrated on the textual features of the novel and introducing the narrator of each chapter and complex nature of the novel. He also has mentioned more details about the confusion of characters' names and different font types indicating different and overlapping stream of thoughts employed by Faulkner. Although both translators have followed the font type pattern of the original work, but in the first chapter, the chain of memories and events rolling around the narrator's mind has been separated by use of a chronological order, this pattern has been overlooked in both translations. The second chapter of the novel is the most questionable and problematic part in terms of understanding the meaning and following the chain of events, and also it has been proven by the analysis. The second chapter includes overlapping clauses, repetition of single names and events, different flashbacks to previous memories and scenes that indicate the narrator's puzzlement and confusion. Among these problematic features, the key problem with this chapter is lack of coherence [situational coherence] and cohesion. Owning to this and with regard to the definition of text and texture presented by Halliday(1994), we cannot accept this chapter as a text. Returning to the definition and characteristics of stream of consciousness mentioned earlier, in the field of stream of consciousness, more than anything else, we deal with interior monologue and unuttered speeches which do not follow the certain and definite linguistic and grammatical rules and patterns. The greatest problem of application of Halliday's model for translation of the second chapter is that as a matter of fact, this model does not take account of text without texture. A reasonable approach to tackle this problem could be to adopt a suitable translation strategy, for this purpose the best choice is adaptation. Another logical reason for the use of such a strategy refers to a considerable amount of elliptical clauses in the body of the original text in which the mood structures have been removed. The elliptical elements can be identified through the cotext [the preceding and following clauses], conversely, subject and finite as elliptical elements of the original clauses have been conflated with predicator in both translations, or their functions have changed in the translation process. To certain extent, translators have succeeded to convey the intended meaning of the source text by the use of such a kind of shift and changing function of the participant; however, employing ungrammatical syntactic structures which can be considered as one of the most significant features of stream of consciousness has been distorted. 
Taken together, these results suggest that from a Hallidayan perspective, both translators have failed to reconstruct stream of consciousness writing style in the target language especially in elliptical clauses in which the mood structures has been removed by the author. In order to overcome this failure, we need to employ adaptation and recreation of the original work in Persian language.

\section{REFERENCES}

[1] Abrams, M. H. (1999). A glossary of literary terms. ( $7^{\text {th }}$ ed.). Massachusetts: Heinle \& Heinle, a devision of Thomson Learning.

[2] Baker, M. (1992). In other words: A coursebook on translation. New York: Routledge.

[3] Bassnett, S. (2002). Translation studies. New York: Routledge.

[4] Bosseaux, Ch. (2007). How does it feel?: Point of view in translation: The case of Virginia Woolf into French. Amsterdam: Rodopi.

[5] Chang, S. (1993). Modernism and the nativist resistance: Contemporary Chinese fiction from Taiwan. Durham: Duke University Press.

[6] Eggins, S. (1994). An introduction to systemic functional linguistics. London: Continuum International Publishing Group.

[7] Faulkner, W. (1995). The Sound and the Fury. New York: Vintage.

[8] Fargnoli, A. N. \& Golay, M. \& Hamblin, R. W. (2008). Critical companion to William Faulkner: A literary reference to his life and work. New York: Facts On File, Inc.

[9] Halliday, M. A. K. (1994). An introduction to functional grammar. (2 $2^{\text {nd }}$ ed.). London: Edward Arnold.

[10] Halliday, M. A. K. \& Hasan, R. (1976). Cohesion in English. London: Longman.

[11] Halliday, M. A. K. \& Hasan, R. (1989). Language, context, and text: Aspects of language in a social-semiotic perspective. Oxford: Oxford University Press.

[12] Horri, A. (2009). Style in translation: Saleh Hosseini's style through translation universals In his Persian translation of Faulkner's The Sound and the Fury. Retrieved November 12, 2011, from, http://journals.ut.ac.ir/page/articleframe.html?langId=en\&articleId=692765

[13] Hosseini, S. (2009). Khashm o hayahoo. Tehran: Niloofar.

[14] Humphrey, R. (1954). Stream of consciousness in the modern novel. California: University of California Press.

[15] Kao, Y. \& Wu, Y. (2011). Translating stream of consciousness in the light of adaptation: A case study of Faulkner's Quentin. Retrieved November 12, 2011, from, http://www.google.co.uk/url?sa=t\&rct=j\&q=\&esrc=s\&frm=1\&source=web\&cd=1\&ved= 0CFEQFjAA\&url=http $\% 3 \mathrm{~A} \% 2 \mathrm{~F} \% 2 \mathrm{Fwww}$. tran.hkbu.edu.hk\%2Fhktransym2011\%2Fhktransym2011_abstractenglish.pdf\&ei=8 S_vT5CHLcza4QSVpr35DQ\&usg=AFQjCNGiZKpPM5Ob5X8qPCrgcHMV9nIfIQ\&sig2=3ViSHo-0K7_91V9_9gQQfg

[16] Munday, J. (2001). Introducing translation studies theories and applications. New York: Routledge.

[17] Nord. C. (2005). Text analysis in translation. Amsterdam: Rodopi.

[18] Pakravan, H. (2002). Negareshi vizhe be nemoode majhool dar zabane Farsi. Shiraz University Journal of Humanities, 35, 3552.

[19] Sholevar, B. (2004). Khashm o hayahoo, Tehran: Negah.

[20] Volpe, E. L. (2003). A reader's guide to William Faulkner: The Novel. Syracuse: Syracuse University Press.

[21] Wang, Q. (2011). Looking for translator's fingerprints: A corpus-based study on Chinese translation of Ulysses. Retrieved November 12, 2011, from, http://llc.oxfordjournals.org/content/27/1/81.short?rss=1

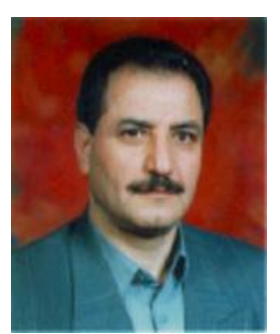

Mohammad Reza Talebinezhad is a faculty member of department of English language, university of Isfahan, Isfahan-Iran. He is interested in interlanguage development, SLA and metaphoricity of language. He is involved in three research projects at the moment: one dealing with learning strategies and how they may be trained; the other with metaphorical language and how second language learners perceive them .The third area of his present research is in culture, SLA and translation studies. Some of his publications are as follows:

1. Transferability of Speech Acts in Persian-English IL in the Proceedings of the Conference on Language, Intelligence and Interpretation Isfahan: 2000. 2. Collocational Clashes and Collocational Errors in the Proceedings of $3 r d$ Tabriz. 3. Talebinezhad, M.R.and Vahid,H.(2001).Poetry Appreciation in ELT. Iranian Journal of Applied Linguistics vol.2, No.2. 4. Talebinezhad, M.R.and Vahid,H. (2005). Animal Metaphors: When Owls are Not Wise. Journal of Metaphor and Symbol, 2005. 5. Talebinezhad, M.R. and Vahid,H. (2005).Cloze and CPD Tests in Language Teaching. In Press. Language Testing, 2005.

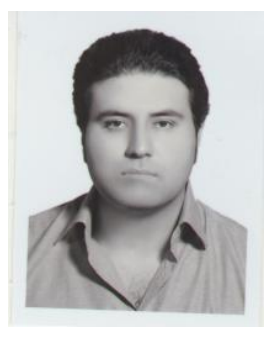

Pooria Alirezazadeh is a student of MA in translation studies, Islamic Azad University, Shahreza branch, Shahreza, Isfahan-Iran. He enjoys the challenges of creativity and attention to details. Linguistic approach towards translation has always a source of wonder for him. He is a passionate researcher of Discourse Analysis, Systemic Functional Linguistics and foreign literature. 